\title{
Molecular identification, biomass, and biochemical composition of the marine chlorophyte Chlorella sp. MF1 isolated from Suez Bay
}

Mostafa El-Sheekh ${ }^{1 *}$ D, Mahmoud Abu-Faddan², Atef Abo-Shady ${ }^{1}$, Mohamed Zein Alabedin Nassar $^{2}$ and Wagdy Labib²

\begin{abstract}
Background: An Egyptian indigenous unicellular green microalga was isolated from the coastal water of Suez Bay

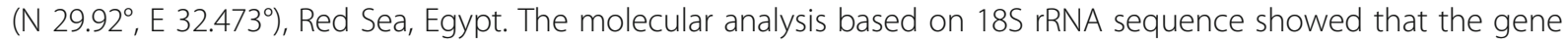
sequence for this strain was highly similar (100\% identity and $98 \%$ query cover) to different Chlorella strains isolated from different habitats.

Results: The observed morphological characters together with the molecular phylogeny assigned the isolated microalga as Chlorella sp. MF1 with accession number KX228798. This isolated strain was cultivated for estimation of its growth and biochemical composition. The mean specific growth rate $(\mu)$ was 0.273 day $^{-1}$. Both the biomass productivity and the cellular lipid content increased by increasing salinity of the growth medium, recording a maximum of $6.53 \mathrm{gDw}^{-1}$ and $20.17 \%$, respectively, at salinity 40.4 . Fourteen fatty acids were identified. The total saturated fatty acid percentage was $54.73 \%$ with stearic (C18:0), arachidic (C20:0), and palmitic acids (C16:0) as major components, while the total unsaturated fatty acid percentage was $45.27 \%$ with linoleic acid (C18:2c) and oleic acid (C18:1) as majors.

Conclusion: This algal strain proved to be a potential newly introduced microalga as one of the most proper options available for microalgae-based biodiesel production. The proximate analysis showed the protein content at $39.85 \%$ and carbohydrate at $23.7 \%$, indicating its accessibility to various purposes.
\end{abstract}

Keywords: 185 rRNA, Growth, Biomass, Lipid, Fatty acids, Carbohydrate, protein, Chlorella sp

\section{Background}

Microalgae are a ubiquitous group of fast-growing unicellular or simple multicellular microphototrophs. Environmentally, microalgae cultivation is considered a promising solution which mitigates global warming via sequestering the primary atmospheric greenhouse gas, $\mathrm{CO}_{2}$, by photosynthesis $[1,2]$. Screening of local microalgae species with high nutritional value and potential

\footnotetext{
* Correspondence: mostafaelsheikh@science.tanta.edu.eg

${ }^{1}$ Botany Department, Faculty of Science, Tanta University, Tanta, Egypt Full list of author information is available at the end of the article
}

for oil production is essential to achieve successful commercial large-scale cultures. The species of the genus Chlorella are considered as cryptic species that are morphologically similar but genetically distinct $[3,4]$. The lack of obvious morphological taxonomic characteristics in addition to an exclusively asexual reproductive cycle by means of autospores makes it difficult to differentiate between the species of the genus Chlorella Beijerinck depending on the traditional taxonomy [5]. Sequences for 18S rRNA gene were used to identify several microalgal species and in particular to differentiate species of Chlorella $[6,7]$. In recent years, microalgae achieve high

\section{Springer Open}

(- The Author(s). 2020 Open Access This article is licensed under a Creative Commons Attribution 4.0 International License, which permits use, sharing, adaptation, distribution and reproduction in any medium or format, as long as you give appropriate credit to the original author(s) and the source, provide a link to the Creative Commons licence, and indicate if changes were made. The images or other third party material in this article are included in the article's Creative Commons licence, unless indicated otherwise in a credit line to the material. If material is not included in the article's Creative Commons licence and your intended use is not permitted by statutory regulation or exceeds the permitted use, you will need to obtain permission directly from the copyright holder. To view a copy of this licence, visit http://creativecommons.org/licenses/by/4.0/. 
potential as a feedstock for biofuel production due to their several advantages such as higher biomass productivity, lesser water demand, and no agricultural land requirement compared to other energy crops [1, 8]. Furthermore, microalgae production and accumulation of proteins, carbohydrates, lipids, and carotenoids are of particular importance when the microalgae are cultivated either to feed human and marine animals or to produce specific valuable substances, for instance [9]. All recent applications on microalgae are favored by high productivity and a precious chemical profile of the cultivated species. However, the chemical content of microalgae varies widely due to differences with culture density, age, changes in culture conditions, methods of measurement used, and the physiological state of the microalgae and to the growth phase of the culture $[10,11]$. Continuous and semi-continuous cultures have gained attention not only for providing a constant source of microalgal biomass, but also for permitting precise manipulation of their biochemical composition [12]. The growth rate of most microalgae species and their biochemical composition, the protein, lipid, and carbohydrate contents, are influenced by alteration in the physiochemical parameters of the growth medium such as light intensity, $\mathrm{pH}$, salinity, temperature, and nitrogen [13, 14]. The ability to constantly sense and rapidly adapt to environmental changes is paramount for microalgae to maintain cellular functions (homeostasis) [15]. Salinity is one of the most important factors affecting the growth of marine microalgae [16]. Generally, microalgae biomass comprises 40$60 \%$ proteins, $20-30 \%$ carbohydrates, and $10-20 \%$ lipids [17]. Lipids are a very attractive feedstock for biofuel production because of their high energy content and easy transforming to biodiesel [18]. The fatty acid composition of the algal lipids is a significant determinant of the biodiesel quality [19]. The most important properties of biofuel, such as cetane number and kinematic viscosity, are highly associated with the structural features of fatty acids [20, 21]. Recently, the lipid-free microalgal biomass plays an important role for economic biodiesel production, could be anaerobically digested for biomethane production [22], enhances the nutritional value of conventional food preparations [23], and can benefit terrestrial plant growth as a fertilizer [18]. The carbohydrate content of microalgae is mainly used as a feed source for livestock or in aquaculture for production of bivalve, crustaceans, and some fish species [24]. Also, carbohydrates can be used as a sugar source in an alcohol fermentation process for bioethanol production [25, 26]. Furthermore, microalgae are a very promising source for the synthesis of single cell protein or microbial protein that is a candidate to be sustainable future protein source to fill the deficit of the human need for protein [27].
This study aimed to isolate, identify, and assess growth and chemical composition of a marine chlorophyte, Chlorella sp. MF1, in continuous culture in the context of the possible use of microalgae as food species in mariculture and as feedstock for biofuel production.

\section{Methods}

\section{Isolation and culturing of a microalga}

A microalga was isolated from water samples collected in July 2013 from the coastal water at of Suez Bay (N $29.92^{\circ}$, E $32.473^{\circ}$ ), Egypt. It was morphologically identified under a microscope as Chlorella sp. Isolation and purification were performed by micropipette washing and streak plating techniques according to Phang and Chu [28] using BG11 medium.

\section{Molecular analysis}

Cells of Chlorella sp. were harvested at the exponential growth phase by centrifugation. The algal pellet was washed three times with polysaccharide elimination buffer [29]. The DNA was extracted, to amplify the sequences of $18 \mathrm{~S}$ ribosomal RNA gene, using the protocol of GeneJet Plant genomic DNA purification Kit (Thermo) \# K0791. PCR amplification of the partial $18 \mathrm{~S}$ ribosomal RNA genes was performed using the following primer set: the forward oligo $\left(5^{\prime}\right.$-CCT GGT TGA TCC TGC CAG-3') and the reverse oligo (5'-A/TTG ATC CTT CT/CG CAG GTT CA-3'). Polymerase chain reaction (PCR) was carried out using Maxima Hot Start PCR Master Mix (Thermo) \#K0221 using the recommended thermal cycling conditions outlined in Table 1. Evolutionary analyses were conducted in MEGA6 software [30] using the maximum likelihood method based on the Kimura 2parameter model [31].

\section{Culture conditions}

The microalgal strain Chlorella sp. MF1. (Accession No: KX228798), isolated from Suez Bay, was grown in BG11 broth medium [32] using filtered autoclaved seawater (salinity 40.4 and $\mathrm{pH}$ of 7.5). The culture was incubated for 15 days at $29 \pm 1{ }^{\circ} \mathrm{C}$ in sterile $1000 \mathrm{~mL}$ Erlenmeyer flasks containing $500 \mathrm{~mL}$ media with $10 \%$ inoculum. The culture was provided with light/dark conditions of $16: 8 \mathrm{~h}$ and gently daily agitated.

\section{Microalgal growth determination}

The growth of the culture was measured every $24 \mathrm{~h}$ using two different methods: determining cell densities (cells/ml) using a hemocytometer cell counting [33], and measuring the optical density (OD) at a wavelength of $750 \mathrm{~nm}$ as recommended by Griffiths et al. [34] by a UV/V spectrophotometer (JENWAY 6705, Staffordshire, UK). All measurements were done 
Table 1 PCR conditions used in this study

\begin{tabular}{cccc}
\hline Step & $\begin{array}{c}\text { Temperature } \\
\left({ }^{\circ} \mathrm{C}\right)\end{array}$ & $\begin{array}{c}\text { Time } \\
(\mathrm{min} .)\end{array}$ & $\begin{array}{c}\text { Number } \\
\text { of cycles }\end{array}$ \\
\hline Initial denaturation & 95 & 10 & 1 \\
\cline { 1 - 3 } Denaturation & 95 & 0.5 & \\
\cline { 1 - 3 } Annealing & 55 & 1 & \multirow{2}{*}{35} \\
\cline { 1 - 3 } Extension & 72 & 1 & \\
\hline Final Extension & 72 & 15 & 1 \\
\hline
\end{tabular}

in triplicate. The mean specific growth rate $(\mu)$ in the exponential phase was calculated by averaging $\mu_{1}$ and $\mu_{2}$, using the following equation:

$$
\mu\left(\text { day }^{-1}\right)=\left[\mu_{1}+\mu_{2}\right] / 2
$$

where $\mu_{1}$ is the slope of the regression line detected from the regression equation that relates time $(T)$ to the natural logarithm of cell density in the exponential phase (ln $\mathrm{CD} \mathrm{m} l^{-1}$ ) calculated as $\ln \mathrm{CD} \mathrm{ml}^{-1}=$ constant + $\mu_{1}^{*} T$. $\left(\mu\right.$, day $\left.^{-1}\right), \mu_{2}$ as $\left[\ln X_{2}-\ln X_{1}\right] /\left[t_{2}-t_{1}\right]$, where $X_{2}$ and $X_{1}$ are the optical density $\left(\mathrm{OD}_{750}\right)$ at $t_{2}$ and $t_{1}$ respectively. The generation (doubling) time $(g)$ was expressed as $g$ (day) $=\ln (2) / \mu$. The growth rate constant $(K)$ expressed in terms of $g$ as $K\left(\right.$ generations day $\left.{ }^{-1}\right)=1 /$ $g$. The maximum biomass $(M)$ is calculated as follows: $\left.M(\text { cell ml})^{-1}\right)=M_{t}-M_{0}$, where $M_{t}$ is the number of cells in the stationary phase with the maximum cell number and $M_{0}$ is the inoculum number of cells. The equation of $\mu_{2}$ followed Liang et al. [35], and the others Madigan et al. [36].

Two liters of algal culture were harvested at late the logarithmic phase and used for further experiments, and the algal biomass was recovered from the medium by centrifugation $(4500 \mathrm{rpm}, 10 \mathrm{~min})$. Then, the obtained cell biomass was lyophilized and stored at $-20^{\circ} \mathrm{C}$ [37] for the subsequent analysis of protein and carbohydrate contents.

Effect of salinity on biomass production and lipid content Five salinity treatments $(0.42,8.41,17.7,28.28$, and 40.4), each with three replicates, were conducted by mixing the fresh tap water (FW) with the filtered seawater $(\mathrm{SW})$ in different proportions, $100 \% \mathrm{FW}$, $75 \% \mathrm{FW}+25 \% \mathrm{SW}, 50 \% \mathrm{FW}+50 \% \mathrm{SW}, 25 \% \mathrm{FW}$ $+75 \%$ SW, and finally $100 \%$ SW. The cultures were aerated using an air pump. Microalgae are harvested at the end of the logarithmic phase by centrifugation at $4500 \mathrm{rpm}$ for $10 \mathrm{~min}$, washed twice with distilled water, and dried in an oven at $80^{\circ} \mathrm{C}$ for $4 \mathrm{~h}$.
The total biomass was then determined gravimetrically and expressed in $\mathrm{g} \mathrm{L}^{-1}$. The total lipid for each treatment was extracted using the modified method of Bligh and Dyer [38] with chloroformmethanol solvent. The solvent was removed by evaporation at $40{ }^{\circ} \mathrm{C}$ after, and the lipid content was determined gravimetrically. The major fatty acid composition was determined for lipid extracted from salinity 40.4 treatment, using GC analysis, according to Radwan [39].

\section{Estimation of protein and carbohydrate contents}

Total carbohydrate content was measured following the method developed by Dubois et al. [40] as adopted by Herbert et al. [41]. Glucose standard solution was used to obtain a calibration curve, which was employed to calculate the carbohydrate content of the samples. Total soluble protein was determined quantitatively applying the method described by Lowry et al. [42]. The extinction was measured at $760 \mathrm{~nm}$ against blank. Using a calibration curve, constructed with bovine serum albumin as a reference, the protein concentration was estimated.

\section{Statistical analysis}

Results are presented as the mean \pm standard deviation (SD) from three replicates. Differences between treatments for the different measured variables were tested by one-way variance (ANOVA), followed by Tukey's (HSD) test when significant differences were found $(p<$ 0.05) in XLSTAT Version 2014.5.03.

\section{Results}

\section{Morphology}

The target microalgal isolate species examined with light microscopy (Fig. 1) was found to be green, unicellular, and spherical (coccoid) or subspherical. Chloroplast was parietal and cup-shaped with a single pyrenoid. In morphometric observations, cell diameter was $3-12 \mu \mathrm{m}$. Reproduction was by autosporulation, 


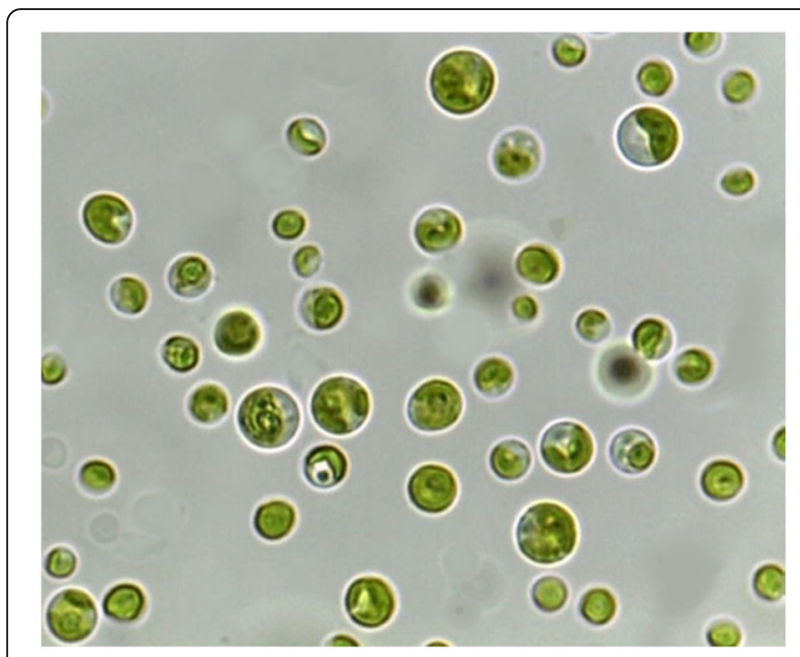

Fig. 1 Photomicrograph of the young and mature vegetative Chlorella sp. MF1 cells under optic microscope $(\times 40)$

leading to two or more daughter cells; sexual reproduction is unknown. The following are the systematics of the species:

\author{
Empire EUKARYOTA \\ Kingdom PLANTAE \\ Phylum CHLOROPHYTA \\ Class TREBOUXIOPHYCEAE \\ Order CHLORELLALES \\ Family CHLORELLACEAE \\ Genus CHLORELLA
}

\section{Phylogeny}

In this study, identification of a Red Sea species of Chlorella was carried out using molecular and phylogenetic analyses of 18S rRNA nuclear gene. The genomic DNA of Chlorella sp. was extracted and the produced amplicons were electrophoresed in the agarose gel. Approximately $535 \mathrm{bp}$ of amplified locus of $18 \mathrm{~S}$ rRNA was observed (Fig. 2). All amplified fragments were sequenced and analyzed against NCBI database. Here, the molecular studies based on 18S rRNA allowed us to identify the isolated strain as Chlorella sp. MF1 with accession number KX228798. The gene sequences for the strain were highly similar (100\% identity and 98\% query cover) to different Chlorella strains isolated from different habitats. Furthermore, It was clearly observed that the sequences have a high percentage similarity which was approximately $100 \%$ with Chlorella sp. CBI small subunit ribosomal RNA gene, partial sequence (Accession No: MH125171) isolated from Indonesia.

The phylogenetic analyses (Fig. 3) resulted in a topology presenting unrooted tree that illustrates the

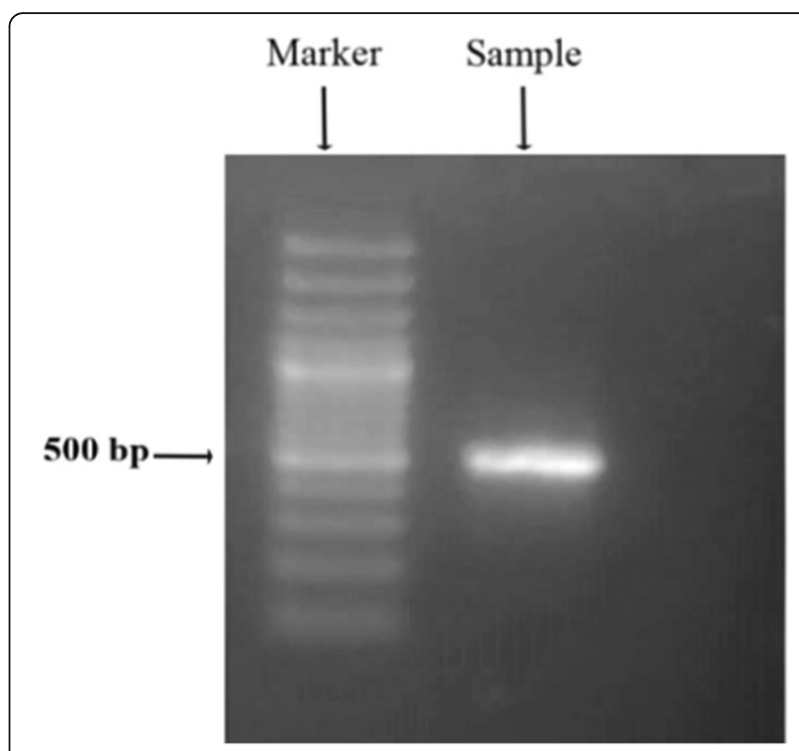

Fig. 2 Agarose gel electrophoreses of the amplified 18S rRNA gene of Chlorella sp. MF1

relatedness of the leaf nodes and reflects the branching order without making assumptions about common ancestry [43]. The phylogenetic tree showed that the sequence of our strain was closely clustered with that of Chlorella sp. KAS603 and Chlorella sp. CBI (Fig. 3).

\section{Biomass productivity}

Chlorella sp. MF1 was cultivated for 2 weeks at salinity 40.4. The growth curve (Fig. 4) was determined after 1 day from incubation, and the growth reached exponential phase at the day 15, almost similar to the duration period of Chlorella marina reported by Muthukumar et al. [37]. The results indicate a significant linear relationship of the

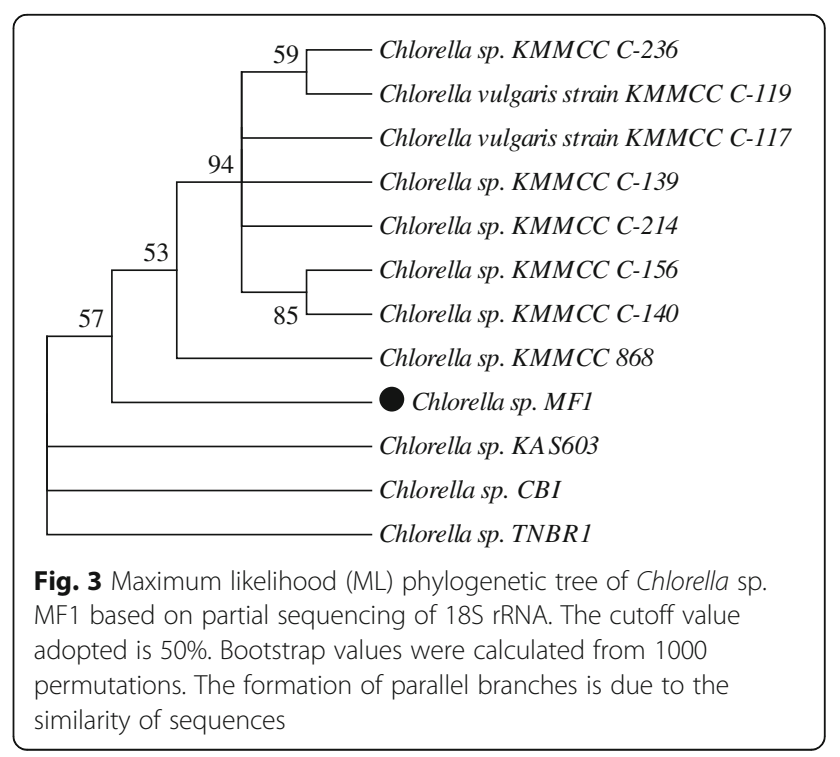




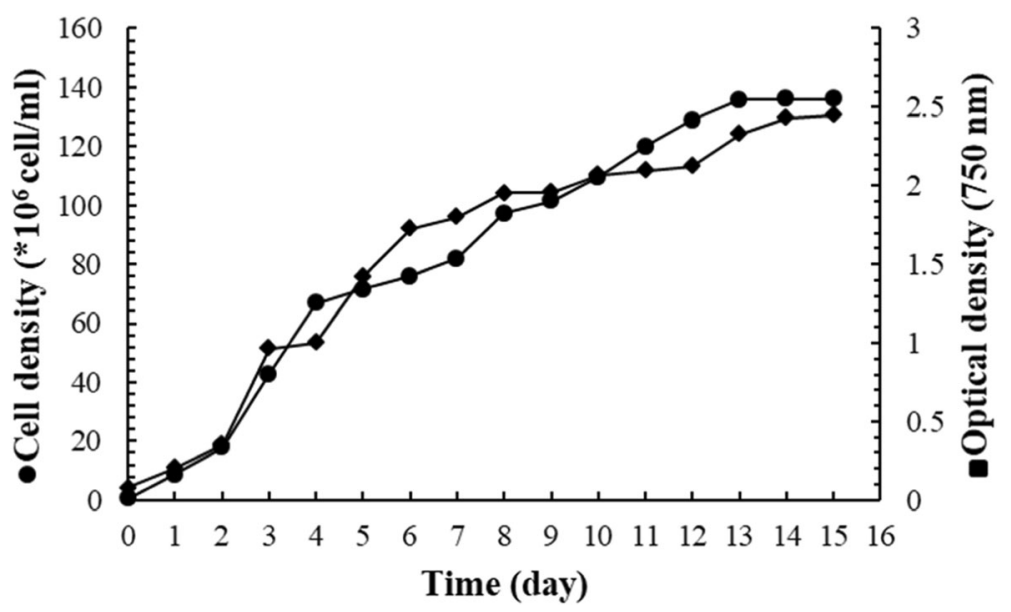

Fig. 4 Chlorella sp. MF1 growth curve in BG11 medium

optical density (OD) at $750 \mathrm{~nm}$ with cells density (CD, cells $* 10^{7} / \mathrm{mL}$ ) as $\mathrm{CD}=56.48 * \mathrm{OD}-4.89$ (Fig. 5); the regression equation relating time $(T)$ to natural logarithm of cell density $(\ln \mathrm{CD} / \mathrm{ml})$ expressed as $\ln \mathrm{CD} / \mathrm{ml}=$ $15.80757+0.2844 * \mathrm{~T}$; the slope of the regression line corresponds to specific growth rate calculated as $\mu_{1}=$ 0.284 day $^{-1}$, while the specific growth rate based on cell density $\left(\mu_{2}\right)$ was at 0.261 day $^{-1}$. Also, the average of $\mu_{1}$ and $\mu_{2}$ resulted in the mean specific growth rate $(\mu)$ equal to $0.273 \pm 0.01 \mathrm{day}^{-1}$. The resulted generation time $(g)$, the mean time required to double the population, was 2.54 days. Consequently, the growth rate constant $(K)$, the number of generations per unit time, was at 0.393 generations/day, and the maximum biomass $(M)$ was $135.65 \times 10^{6}$ cells $/ \mathrm{ml}$ (Table 2 ).

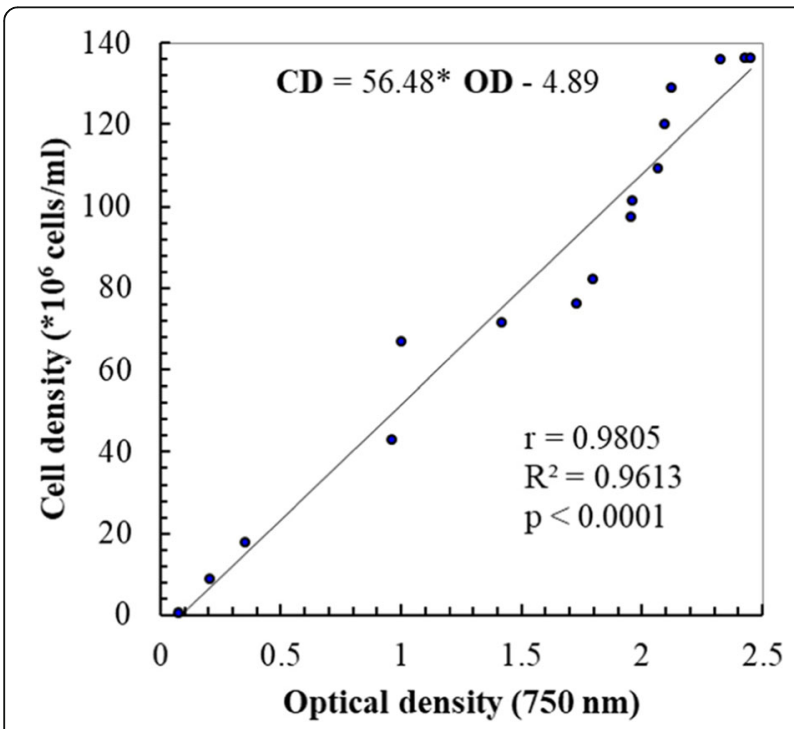

Fig. 5 Relation between cell density and optical density of Chlorella sp. MF1
Effect of salinity on growth rate and lipid content

The results indicated that the biomass productivity ranged from a minimum of $4.147 \pm 0.065 \mathrm{~g}_{\mathrm{DW}} \mathrm{l}^{-1}$ at salinity $0.42(100 \%$ distilled freshwater) to a maximum of $6.53 \pm 0.286 \mathrm{~g}_{\mathrm{DW}} \mathrm{l}^{-1}$ at salinity 40.4 (100\% filtered seawater) with highly significant differences between salinity treatments ( $p<0.05$ by ANOVA) (Fig. 6).

The extracted greenish oil content (\% oil/g of dry algal biomass) from the harvested algae ranged from a minimum of $17.447 \pm 0.667 \%$ at salinity 0.42 to a maximum of $20.17 \pm 0.574$ at salinity 40.4 with significant differences between salinity treatments $(p<$ 0.05 by ANOVA) (Fig. 6).

\section{Fatty acid components}

The results showed that the fatty acid content as a percentage of total lipids (FAC/TL) was 14.13\% (Table 3). The fatty acid content is mainly composed of a mixture of saturated (SFAC) and unsaturated (UFAC) fatty acids as $54.73 \%$ and $45.27 \%$ of total fatty acids, respectively. The major saturated fatty acids were stearic (C18:0), arachidic (C20:0), and palmitic acids (C16:0) while the major unsaturated were linoleic acid (C18:2c) and oleic acid (C18:1) (Table 4).

\section{Protein and carbohydrate contents}

The estimated protein content at the salinity 40.4 was $39.85 \%$ of dry weight, while the carbohydrate content was $23.7 \%$ (Fig. 7 ).

\section{Discussion}

The microscopic observations of this work are in agreement with those recorded for the genus Chlorella Beijerinck $[4,45]$. The phylogenetic analyses resulted in a topology presenting unrooted tree that illustrates the 
Table 2 Growth characteristics of Chlorella sp. MF1 (this study) and other species of Chlorella based on Rosenberg et al. [44]

\begin{tabular}{|c|c|c|c|c|}
\hline $\begin{array}{l}\text { Chlorella species } \\
\text { Growth characteristic }\end{array}$ & C. sp. MF1 & C. protothecoides & C. vulgaris & C. sorokiniana \\
\hline Growth medium & BG11 & \multicolumn{3}{|c|}{ Bold's basal medium (BBM) } \\
\hline Specific Growth Rate, $\mu\left(\right.$ day $\left.^{-1}\right)$ & 0.273 & 0.326 & 0.236 & 0.366 \\
\hline Generation Time, g (day) & 2.54 & 2.17 & 3.00 & 1.92 \\
\hline Growth rate constant, $\mathrm{K}$ (generations/day) & 0.393 & 0.462 & 0.333 & 0.522 \\
\hline Lipid content ( $\%$ dry weight) & 21.1 & 12 & 18 & 18 \\
\hline
\end{tabular}

relatedness of the leaf nodes and reflects the branching order without making assumptions about common ancestry [43]. The rooted trees are ideally preferable, but almost every phylogenetic reconstruction algorithm provides an unrooted tree [46]. A polytomy or multifurcation is observed where there is no branching order consistent with $50 \%$ or more of the replicate trees. This reflects that bootstrap replications fail to support a branch in less than $50 \%$ of resamplings [47]. Also, polytomies reflect poorly resolved or conflicting relationships [48]. Future analyses of this data by other methods of phylogenetic inference may interpret some features of this tree. On the other hand, Basic Local Alignment Search Tool of the National Center for Biotechnology Information (NCBI BLAST) of Chlorella sp. MF1 sequence has shown close relationships (100\% identity and $98 \%$ query cover) between highly dissimilar morphologies such as Dicloster acuatus strain
Xmm25W2 and Dictyosphaerium sp. YN12-4, demonstrating that evolution of vegetative morphology can be rapid [49].

The growth of Chlorella sp. MF1 reached exponential phase at the day 15, almost similar to the duration period of Chlorella marina reported by Muthukumar et al. [37]. The resulted generation time $(g)$, the mean time required to double the population, was 2.54 days. Consequently, the growth rate constant $(K)$, the number of generations per unit time, was at 0.393 generations/day; and the maximum biomass $(M)$ was $135.65 \times 10^{6}$ cells $/ \mathrm{ml}$. This agrees to some extent with the results reported by Rosenberg et al. [44] for different Chlorella spp. The maximum biomass production is similar to that recorded for Chlorella vulgaris by Montoya et al. [50] using nitrogen-limited Bold basal medium provided with $4 \% \mathrm{CO}_{2}$-enriched air, also by El-Mohsnawy et al. [51] under limited

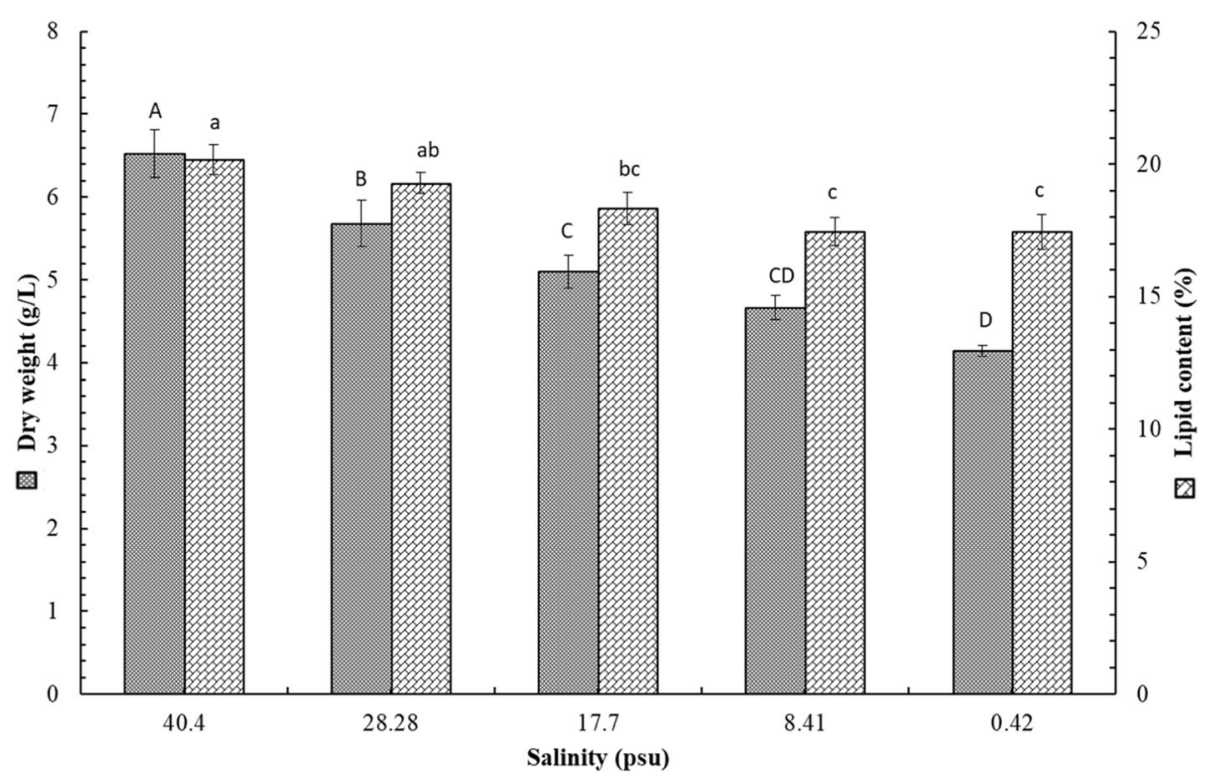

Fig. 6 Biomass productivity $\left(\mathrm{g} \mathrm{I}^{-1}\right.$ ) and oil content (\% oil/g of dry algal biomass) of Chlorella sp. MF1 under different salinity treatments. Different letters indicate statistically significant differences between the treatments using Tukey's test 
Table 3 Total lipid content as percentage of dry mass (TLDM), saturated fatty acid content as percentage of total lipids (SFAC/TL) and total fatty acids (SFAC/TFA) and monounsaturated and polyunsaturated fatty acid content as percentages of total fatty acids (MUFAC/TFA and PUFAC/TFA, respectively) and of total lipids (MUFAC/TL and PUFAC/TL, respectively) and total fatty acid contents in the microalgae dry biomass

\begin{tabular}{|c|c|c|c|c|c|c|}
\hline TLDM & \multicolumn{5}{|c|}{21.1} & \multirow{7}{*}{$\%$} \\
\hline \multirow{3}{*}{$\mathrm{FAC} / \mathrm{TL}$} & \multirow{3}{*}{14.13} & SFAC/TL & & 7.72 & & \\
\hline & & \multirow{2}{*}{ UFAC/TL } & \multirow{2}{*}{6.39} & MUFAC/TL & 2.47 & \\
\hline & & & & PUFAC/TL & 3.9 & \\
\hline SFAC/TFA & & & 54.73 & & & \\
\hline \multirow{2}{*}{ USFAC/TFA } & \multirow{2}{*}{45.27} & MUFAC/TFA & & 17.5 & & \\
\hline & & PUFAC/ TFA & & 27.7 & & \\
\hline
\end{tabular}

nitrogen and mixotrophic condition. The results indicated that the mean growth rate increased with increasing salinity in agreement with El-Sheekh et al. [8] who concluded that growing Chlorella vulgaris. under salt supplemented Kuhl medium $(10 \mathrm{~g} / \mathrm{l} \mathrm{NaCl})$ produces high biomass and oil for biodiesel production. However, Battah et al. [52] interpreted the growth inhibition of Chlorella vulgaris in response to salinity increase as a result of shifting the metabolites to the synthesis of osmoregulant compounds rather than synthesis of cellular constituents. The positive relation observed between the biomass productivity and salinity might be related to the excess of nutrients associated with the filtered seawater. Seawater contains more dissolved ions than all types of freshwater [53]. Generally, the higher seawater percentage in the growth medium, i.e, the higher salinity, leads to more nutrient loading in the medium and thereby increases biomass productivity. The role of salinity as an important stressor has been intensively investigated with different experimental techniques to spur lipid anabolism for biodiesel production [52, 54]. The extracted greenish oil content (\% oil/g of dry algal biomass) from the harvested algae ranged from a minimum of $17.447 \%$ at salinity 0.42 to a maximum of 20.17 at salinity 40.4 with significant differences between salinity treatments, almost similar to that reported by Rosenberg et al. [44] for Chlorella vulgaris and Chlorella sorokiniana. Also, the results reinforce the conclusion that increasing salinity within a range

Table 4 Fatty acid composition (\% of total fatty acids) of Chlorella sp. MF1

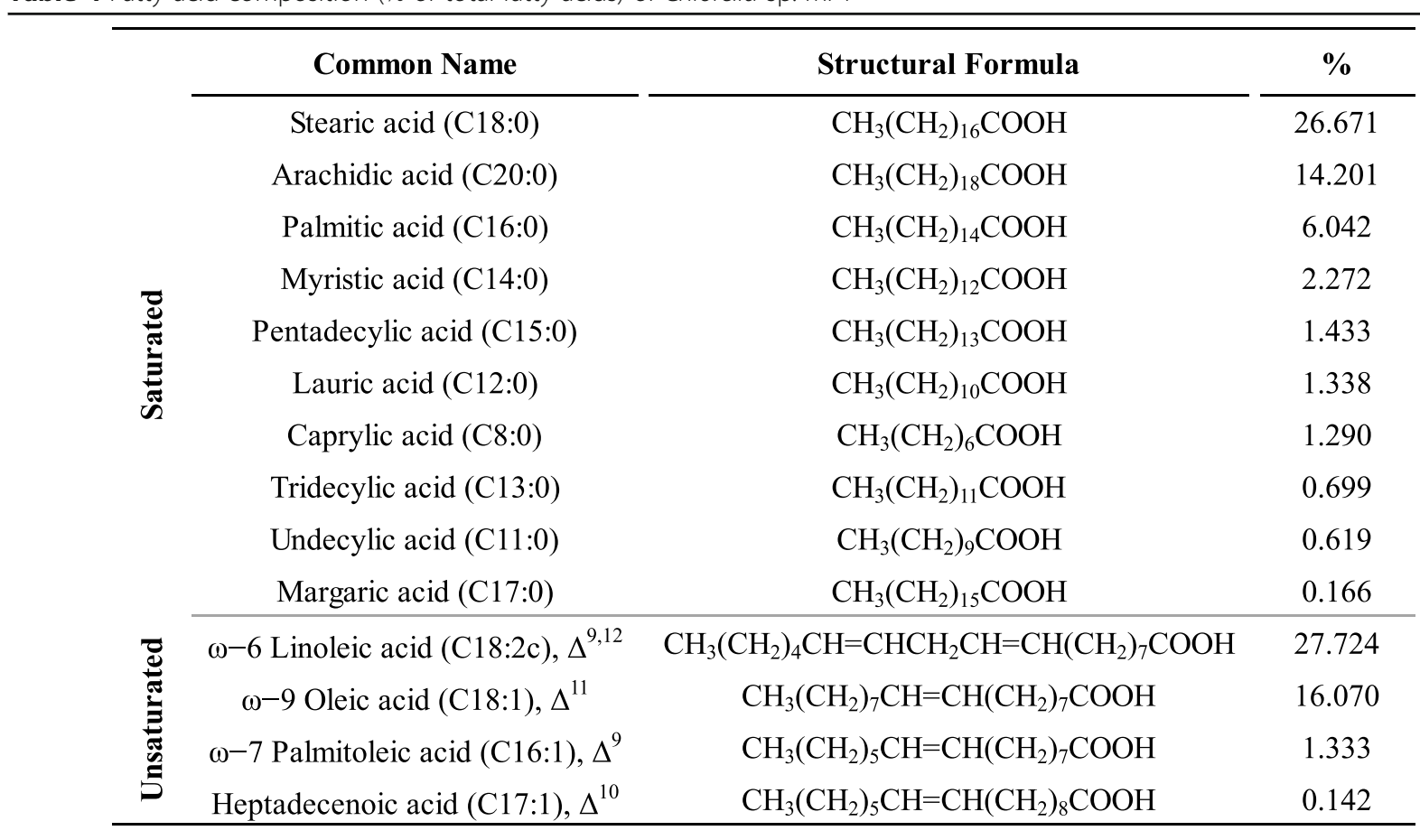



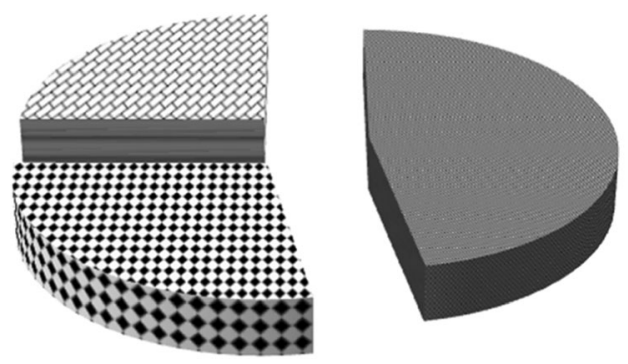

- Protein $(39.85 \%)$

:: Carbohydrate (23.7\%)

s Lipid (21.1\%)

Fig. 7 The biochemical composition of Chlorella sp. MF.1 (as percentage of dry weight)

that is specific for each species leads to increased cell lipid content as in Navicula sp. [55], Dunaliella tertiolecta [56], Nannochloropsis oculata [57], and Chlorella vulgaris [52].

The results showed that the fatty acid content as a percentage of total lipids (FAC/TL) was 14.13, close to the percentage of $15.4 \%$, recorded for Chlorella vulgaris by Ohse et al. [58]. The high saturated fatty acid content (54.73\% of TFA) when compared with unsaturated fatty acids (45.27\% of TFA) provides the eligibility as a biodiesel feedstock. Production of biodiesel containing high saturated fatty acids is less susceptible to oxidation and rancidity [59]. These obtained results favor the marine microalga Chlorella sp. MF1 to be used as feedstock for biodiesel production and also as food and feed additives. Battah et al. [52] also recorded quasisymmetric percentages, 53.99 and $46.01 \%$ respectively, for Chlorella vulgaris cultured in Bold basal medium containing $0.45 \mathrm{mM} \mathrm{NaCl}$. The salt stress on the photosynthetic organisms, such as Chlorella sp. MF1, leads to an increase in desaturation of the fatty acids of membrane lipids $[60,61]$. This increase reinforces the salt tolerance via increasing the plasma membrane viscosity and fluidity, increasing the turgor pressure of the cell and thus preventing the outflux of water from the cells as a mechanism of adaptation [62]. The major saturated fatty acids were stearic (C18:0), arachidic (C20:0), and palmitic acids (C16:0) while the major unsaturated were linoleic acid (C18:2c) and oleic acid (C18:1) (Table 4). These results almost agree with Battah et al. [52] who reported the linoleic acid as the major unsaturated, and palmitic the major saturated. Furthermore, palmitic, stearic, oleic, and linoleic acids were recognized as the most common fatty acids contained in biodiesel [19].

The estimated protein content at the salinity 40.4 was $39.85 \%$ of dry weight, lies in the range of $33-46 \%$, for Chlorella vulgaris cultured under different light regimes [63]. The carbohydrate content was $23.7 \%$, close to that recorded by Kim et al. [64] as $22.4 \%$ for Chlorella vulgaris cultured in Bold basal medium (BBM), but under nitrogen limitation conditions. Also, Laurens et al. [65] reported the total carbohydrate content in microalgae of about $22 \%$ dry weight (DW) and protein content about $44 \%$ DW.

\section{Conclusion}

In conclusion, cultivation of Chlorella sp. MF1 is a new addition to the other species offering advantage as a vital marine source of biofuel production, human consumption, etc., but, further experiments are still needed. The high biomass productivity of such a marine microalgal species and the high contents of protein and fatty acids that have numerous health benefits indicate the accessibility to the previous purposes. Furthermore, it could be cultivated in seawater-enriched medium to save freshwater resources.

\section{Abbreviations \\ PCR: Polymerase chain reaction; OD: Optical density; CD: Cell density; SFAC: Saturated fatty acids; UFAC: Unsaturated fatty acids; NCBI BLAST: Basic Local Alignment Search Tool of the National Center for Biotechnology Information; DM: Dry mass; TL: Total lipids}

\section{Acknowledgements}

Not applicable

\section{Authors' contributions}

MA-F carried out the experimental work. ME, AA-S, and WL supervised and suggested the problem. MZAN helped in the experimental work. All authors contributed to the writing of the draft, and ME finalized the manuscript in the final form. All authors have read and approved the manuscript

\section{Funding}

No

Availability of data and materials

All the data required for the processing of the conclusions are presented in the "Results" section.

Ethics approval and consent to participate

Not applicable.

Consent for publication

Not applicable.

\section{Competing interests}

The author(s) declare that they have no competing interests.

\section{Author details}

${ }^{1}$ Botany Department, Faculty of Science, Tanta University, Tanta, Egypt. ${ }^{2}$ Marine Environment Division, National Institute of Oceanography and Fisheries, Cairo, Egypt. 
Received: 8 May 2020 Accepted: 26 June 2020

\section{Published online: 09 July 2020}

\section{References}

1. Wang B, Li Y, Wu N, Lan CQ (2008) $\mathrm{CO}_{2}$ bio-mitigation using microalgae. Appl Microbiol Biotechnol 79:707-718

2. Satpati GG, Pal R (2018) Microalgae-biomass to biodiesel: a review. J Algal Biomass UtIn 9(4):11-37

3. Müller J, Friedl T, Hepperle D, Lorenz M, Day JG (2005) Distinction between multiple isolates of Chlorella vulgaris (Chlorophyta, Trebouxiophyceae) and testing for conspecificity using amplified fragment length polymorphism and ITS rDNA sequences. J Phycol 41(6):1236-1247

4. Baytut Ö, Gürkanli CT, Gönülol A, Özkoç I (2014) Molecular phylogeny of Chlorella-related chlorophytes (Chlorophyta) from Anatolian freshwaters of Turkey. Turk J Bot 38(3):600-607

5. Huss V, Frank C, Hartmann E, Hirmer M, Kloboucek A, Seidel B, Wenzeler P, Kessler E (1999) Biochemical taxonomy and molecular phylogeny of the genus Chlorella sensu lato (Chlorophyta). J Phycol 35:587-598

6. Wan M, Rosenberg JN, Faruq J, Betenbaugh MJ, Xia J (2011) An improved colony PCR procedure for genetic screening of Chlorella and related microalgae. Biotechnol Lett 33:1615-1619

7. Tear C, Lim C, Wu J, Zhao H (2013) Accumulated lipids rather than the rigid cell walls impede the extraction of genetic materials for effective colony PCRs in Chlorella vulgaris. Microb Cell Factories 12(1):106-112

8. El-Sheekh MM, Gheda SF, El-Sayed A, Abo Shady A, El-Sheikh M, Schagerl M (2019) Outdoor cultivation of the green microalga Chlorella vulgaris under stress conditions as a feedstock for biofuel. Environ Sci Pollut Res 26:1852018532

9. Machado RR, Lourenço SO (2008) Propriedades nutricionais de microalgas usadas como alimento de moluscos bivalves: uma revisão. Museu Nacional, Série Livros 30:281-304

10. Borges-Campos V, Barbarino E, Lourenço SO (2010) Crescimento e composição química de dez espécies de microalgas marinhas em cultivos estanques. Cienc Rural 40:339-347

11. Paes CRPS, Faria GR, Tinoco NAB, Castro DJFA, Barbarino E, Lourenco SO (2016) Growth, nutrient uptake and chemical composition of Chlorella sp. and Nannochloropsis oculata under nitrogen starvation. Lat Am J Aquat Res 44(2):275-292

12. Ferreira M, Coutinho P, Seixas P, Fábregas J, Otero A (2009) Enriching rotifers with 'premium' microalgae Nannochloropsis gaditana. Mar Biotechnol 11:585-595

13. El-Sheekh MM, Abomohra A, Abd El-Azim M, Abou-Shanab R (2017) Effect of temperature on growth and fatty acids profile of the biodiesel promising microalga Scenedesmus acutus. Biotechnology Agronomy Soc. Environment 21(4):233-239

14. Liang G, Mo Y, Tang J, Zhou Q (2011) Improve lipid production by pH shifted strategy in batch culture of Chlorella protothecoides. Afr J Microbiol Res 5:5030-5038

15. López-Maury L, Marguerat S, Bähler J (2008) Tuning gene expression to changing environments: From rapid responses to evolutionary adaptation. Nat Rev Genet 9(8):583-593

16. Zhila NO, Kalacheva GS, Volova TG (2011) Effect of salinity on the biochemical composition of the alga Botryococcus braunii Kütz IPPAS H-252. J Appl Phycol 23:47-52

17. Singh A, Nigam PS, Murphy JD (2011) Mechanism and challenges in commercialization of algal biofuels. Bioresour Technol 102:26-34

18. Gross, M. Development and optimization of novel algal cultivation systems. Master thesis, lowa State University, Food Science and Human Nutrition Department 2013

19. Abomohra A, Shang H, El-Sheekh MM, Eladel H, Ebaid R, Wang S, Wang Q (2019) Night illumination using monochromatic light-emitting diodes for enhanced microalgal growth and biodiesel production. Bioresour Technol 288:121514

20. El-Sheekh MM, El-Gamal A, Bastawess AE, El-Bokhomy A (2017) Production and characterization of biodiesel from the unicellular green alga Scenedesmus obliquus. Energy Sources, Part A: Recovery, Utilization, and Environmental Effects 38(8):783-793

21. El-Sheekh MM, Gheda S, El-Sayed AB, Abo Shady A, El-Sheikh M, Schagerl M (2019) Outdoor cultivation of the green microalga Chlorella vulgaris under culture stress conditions as a feedstock for biofuel. Environ Sci Pollut Res 26: 18520-18532
22. Hernández D, Solana M, Riaño B, García-González MC, Bertucco A (2014) Biofuels from microalgae: lipid extraction and methane production from the residual biomass in a biorefinery approach. Bioresour Technol 170:370-378

23. Spolaore P, Joannis-Cassan C, Duran E, Isambert A (2006) Commercial applications of microalgae. J Biosci Bioeng 101:87-96

24. El-Sheekh M, El-Shourbagy I, Shalaby S, Hosny S (2014) Effect of feeding Arthrospira platensis (Spirulina) on growth and carcass composition of hybrid red tilapia (Oreochromis niloticus x Oreochromis mossambicus). Turk J Fish Aquat Sci 14(2):471-478

25. Harun R, Yip JW, Thiruvenkadam S, Ghani WA, Cherrington T, Danquah MK (2014) Algal biomass conversion to bioethanol-a step-by-step assessment. Biotechnol J 9(1):73-86

26. Ismail M, Ismail G, El-Sheekh MM (2020) Potential assessment of some micro and macroalgal species for bioethanol and biodiesel production. Energy Sources, Part A: Recovery, Utilization, and Environmental Effects (In press). https://doi.org/10.1080/15567036.2020.1758853

27. Upadhyaya S, Tiwari S, Arora N, Singh DP (2016) Microbial protein: a valuable component for future food security. In: Singh JS, Singh DP (eds) Microbes and Environmental Management. Studium Press, New Delhi, pp 259-279

28. Phang SM, Chu WL. (1999) Algae culture Collection, Catalogue of Strains Institute of Post Graduate Studies and Research, University of Malaya, Kuala Lumpur, Malaysia, 77 pp.

29. Wang GG, Li YH, Xia P (2005) A simple method for DNA extraction from sporophyte in the brown alga Laminaria japonica. J Appl Phycol 17(1):75-79

30. Tamura K, Stecher G, Peterson D, Filipski A, Kumar S (2013) MEGA6: Molecular Evolutionary Genetics Analysis version 6.0. Mol Biol Evol 30:27252729

31. Kimura M (1980) A simple method for estimating evolutionary rate of base substitutions through comparative studies of nucleotide sequences. J Mol Evol 16:111-120

32. Stanier RY, Deruelles J, Rippka R, Herdman M, Waterbury JB. (1979) Generic assignments, strain histories and properties of pure cultures of cyanobacteria. Microbiology 111(1):1-61.

33. Guillard RRL, Sieracki MS (2005) Counting cells in cultures with the light microscope. In: Andersen RA (ed) Algal culturing techniques. Elsevier Academic Press, London, pp 239-252

34. Griffiths MJ, Garcin C, Van Hille RP, Harrison STL (2011) Interference by pigment in the estimation of microalgal biomass concentration by optical density. J Microbiol Methods 85(2):119-123

35. Liang F, Wen X, Geng Y, Ouyang Z, Luo L et al (2013) Growth rate and biomass productivity of Chlorella as affected by culture depth and cell density in an open circular photobioreactor. J Microbiol Biotechnol 23(4): 539-544

36. Madigan MT, Bender KS, Buckley DH, Sattley WM, Stahl DA et al (2018) Microbial growth and its control. In: Brock Biology of Microorganisms, 15th edn. Pearson Education, New York, pp 173-208

37. Muthukumar A, Elayaraja S, Ajithkumar TT, Kumaresan S, Balasubramanian T (2012) Biodiesel production from marine microalgae Chlorella marina and Nannochloropsis salina. J Pet Technol Altern Fuel 3(5):58-62

38. Ryckebosch E, Muylaert K, Foubert I (2012) Optimization of an analytical procedure for extraction of lipids from microalgae. J Am Oil Chem Soc 89: 189-198

39. Radwan SS (1978) Sources of C20 polyunsaturated of fatty acids for use. Appl Microbiol Biotechnol 35:421-430

40. Dubois M, Gilles KA, Hamilton JK, Rebers PA, Smith F (1956) Colorimetric method for determination of sugars and related substances. Anal Chem 28: 350-356

41. Herbert D, Phipps PJ, Stravge RE (1971) Determination of total carbohydrates. Methods Microbiol 5(B):390-344

42. Lowry OH, Rosenbrough NJ, Farr AL, Randall RJ (1951) Protein measurement with the folin phenol reagent. J Biol Chem 193:265-275

43. Money NP (2016) Fungal diversity. In: Watkinson SC, Boddy L, Money NP (eds) The fungi, Third Edition. Academic Press, Elsevier, pp 1-36

44. Rosenberg JN, Kobayashi N, Barnes A, Noel EA, Betenbaugh MJ, Oyler GA (2014) Comparative analyses of three Chlorella species in response to light and sugar reveal distinctive lipid accumulation patterns in the microalga $C$. sorokiniana. PLoS One 9(4):e92460

45. Arora M, Sahoo D. Green Algae. In: Sahoo D, Seckbach J, editors. (2015) The Algae World (cellular origin, life in extreme habitats and astrobiology). Springer, Dordrecht, pp. 91-120. 
46. El-Bondkly AMA. (2014) Sequence analysis of industrially important genes from Trichoderma. Biotechnology and Biology of Trichoderma. Elsevier. 377-392.

47. Giovannoni S, Wood N, Huss V (1993) Molecular phylogeny of oxygenic cells and organelles based on small-subunit ribosomal RNA sequences. In: Lewin RA (ed) Origins of Plastids: Symbiogenesis. Prochlorophytes and the Origins of Chloroplasts. Chapman and Hall, New York, pp 159-170

48. Leliaert F, Smith DR, Moreau H, Herron MD, Verbruggen H, Delwiche CF, De Clerck O (2012) Phylogeny and molecular evolution of the green algae. Crit Rev Plant Sci 31(1):1-46

49. Lewis LA, McCourt RM (2004) Green algae and the origin of land plants. Am J Bot 91:1535-1556

50. Montoya EYO, Casazza AA, Aliakbarian B, Perego P, Converti A, De Carvalho JCM (2014) Production of Chlorella vulgaris as a source of essential fatty acids in a tubular photobioreactor continuously fed with air enriched with $\mathrm{CO}_{2}$ at different concentrations. Biotechnol Prog 30(4):916-922

51. EL-Mohsnawy E, El-Sheekh MM, Mabrouk M, Zoheir W (2020) Enhancing accumulation of omega 3 and 9 fatty acids in Chlorella vulgaris under mixotrophic nutrition. The Journal of Animal and Plant Sciences 30(2):485492

52. Battah M, El-Ayoty Y, Abomohra A, El-Ghany SA, Esmael A (2013) Optimization of growth and lipid production of the chlorophyte microalga Chlorella vulgaris as a feedstock for biodiesel production. World Appl Sci J 28:1536-1543

53. Gale, Thomson. Ocean chemical processes) [retrieved December 2, 2006].

54. Talukdar J, Kalita MC, Goswami BC (2012) Effects of salinity on growth and total lipid content of the biofuel potential microalga Ankistrodesmus falcatus (Corda) Ralfs. Int J Sci Eng Res 3:1-7

55. Al-Hasan RH, Ali AM, Ka'Wash HH, Radwan SS (1990) Effect of salinity on the lipid and fatty acid composition of the halophyte Navicula sp., potential in mariculture. J Appl Phycol 2:215-222

56. Takagi M, Karseno K, Yoshida T (2006) Effect of salt concentration on intracellular accumulation of lipids and triacylglyceride in marine microalgae Dunaliella cells. J Biosci Bioeng 101:223-226

57. Gu N, Lin Q, Li G, Tan Y, Huang L, Lin J (2012) Effect of salinity on growth, biochemical composition, and lipid productivity of Nannochloropsis oculata CS 179. Eng Life Sci 12(6):631-637

58. Ohse S, Derner RB, Ozório RÁ, Corrêa RG, Furlong EB, Cunha PCR (2015) Lipid content and fatty acid profiles in ten species of microalgae. Idesia 33(1):93-102

59. Stansell GR, Gray VM, Sym SD (2012) Microalgal fatty acid composition: implications for biodiesel quality. J Appl Phycol 24(4):791-801

60. Huflejt ME, Tremolieres A, Pineau B, Lang JK, Hatheway J, Packer L (1990) Changes in membrane lipid composition during saline growth of the fresh water cyanobacterium Synechococcus 6311. Plant Physiol 94(4):1512-1521

61. Allakhverdiev SI, Kinoshita M, Inaba M, Suzuki I, Murata N (2001) Unsaturated fatty acids in membrane lipids protect the photosynthetic machinery against salt-induced damage in Synechococcus. Plant Physiol 125(4):18421853

62. Singh SC, Sinha RP, Hader DP (2002) Role of lipids and fatty acids in stress tolerance in cyanobacteria. Acta Protozool 41:297

63. Seyfabadi J, Ramezanpour Z, Khoeyi ZA (2011) Protein, fatty acid, and pigment content of Chlorella vulgaris under different light regimes. J Appl Phycol 23(4):721-726

64. Kim KH, Choi IS, Kim HM, Wi SG, Bae HJ (2014) Bioethanol production from the nutrient stress-induced microalga Chlorella vulgaris by enzymatic hydrolysis and immobilized yeast fermentation. Bioresour Technol 153:47-54

65. Laurens LML, Dempster TA, Jones HDT, Wolfrum EJ, Van Wychen S, McAllister JSP, Gloe LM (2012) Algal biomass constituent analysis: method uncertainties and investigation of the underlying measuring chemistries. Anal Chem 84(4):1879-1887

\section{Publisher's Note}

Springer Nature remains neutral with regard to jurisdictional claims in published maps and institutional affiliations.

\section{Submit your manuscript to a SpringerOpen ${ }^{\circ}$ journal and benefit from:}

- Convenient online submission

- Rigorous peer review

- Open access: articles freely available online

- High visibility within the field

- Retaining the copyright to your article

Submit your next manuscript at $\boldsymbol{\nabla}$ springeropen.com 